\title{
Intellectual Capital and Islamic Banks' Performance; Evidence from Indonesia and Malaysia
}

\author{
Rahmat Heru Setianto \\ Department of Management, UniversitasAirlangga
}

rahmat.heru@feb.unair.ac.id

Raditya Sukmana

Department of Islamic Economics, UniversitasAirlangga

momyadit@gmail.com

\begin{abstract}
This paper aims to investigate empirically the relationship between the Intellectual Capital (IC) efficiency consist of human capital, structural capital and capital employed and Islamic banks performance in Indonesia and Malaysia. We employ independent sample t-test and regression analysis focusing on the period from 2010 to 2014. The results suggest that there are significant differences in intellectual efficiency scores, where Islamic Banks in Malaysia have exhibited better VAIC ${ }^{T M}$ scores as compare to that of Islamic banks in Indonesia. While the regression analysis suggest that banks with better human capital efficiency tend to exhibit higher profitability levels. Moreover, sstructural capital is not related to Islamic bank performance. The results also suggets that capital efficiency tend to exhibit higher profitability levels both in Indonesia and Malaysia. The findings may serve as a useful input for Islamic bankers to apply knowledge based management in their respective institutions and in addressing the factors affecting IC performance in order to establish priorities and develop strategic plans, which will in turn enhance their future performance to maximize their value creation.
\end{abstract}

Keywords: Intellectual Capital, Financial Performance, Islamic Banks 


\section{Abstrak}

Penelitian ini bertujuan untuk meneliti secara empiris hubungan antara Intellectual Capital (IC) yang terdiri dari modal manusia, modal structural dan modal financial dengan kinerja bank syariah di Indonesia dan Malaysia. Penelitian ini mengunakan prosedur independent sample t-test dan analisis regresi dengan data tahun antara tahun 2010 sampai 2014. Hasil penelitian menunjukkan bahwa terdapat perbedaan yang signifikan dalam skor efisiensi intelektual, di mana Bank Islam di Malaysia menunjukkan skor VAIC ${ }^{T M}$ lebih baik di bandingkan dengan bank Islam di Indonesia. Sedangkan analisis regresi menunjukkan bahwa bank-bank dengan efisiensi modal manusia yang lebih baik cenderung menunjukkan tingkat profitabilitas yang lebih tinggi. Selain itu, modal structural tidak berpengaruh terhadap kinerja bank syariah. Hasil penelitian juga menunjukan bahwa semakin tinggi efisiensi dalam investasi capital akan menghasilkan profitabilitas yang lebih tinggi baik di Indonesia maupun di Malaysia. Hasil penelitian ini memberikan implikasi penting bagi para bankir Islam untuk menerapkan manajemen berbasis pengetahuan di lembaganya masing-masing, dan mempertimbangkan faktor yang mempengaruhi kinerja IC dalam menetapkan prioritas dan mengembangkan rencana strategis, yang pada gilirannya akan meningkatkan kinerja masa depan mereka untuk memaksimalkan penciptaan nilai mereka.

Kata Kunci: Intellectual Capital, KinerjaKeuangan, Bank Syariah

\section{INTRODUCTION}

In this current modern economy, practitioners and academicians have paid a significant attention on the role of knowledge and Intangible assets (Andriessen, 2004; Bechtel, 2007; Moon and Kym, 2006). They believe this knowledge or intellectual capital (IC) is important component for maintaining the competitive advantage and sustainable corporate 
performance (Mondal and Ghosh, 2012; Hatch and Dyer, 2004; Hitt et al., 2001; Liu et al., 2009; Petty and Guthrie, 2000).Empirical fact has also shown the same resultthat the existence of wealth in the modern economy is no longer depending on physical assets rather it depends on intangible assets (Ghos and Wu, 2007; Abernathy et al., 2003; Bontis et al., 2000; Mavridis, 2004; Chen et al., 2005). Several companies which have been earning profit and maintaining their existence in the present economy are merely depending upon the intangible assets or intellectual assets (Mondal and Ghosh, 2012). Therefore, IC is very important as it is associated with the main source of long term competitive advantage and value for an individual as well as organizational in this era of modern economy (Wiig, 1997).

Increasing attention on the pivotal role played by intellectual capital in value creation process has resulted on various systematic approach of measuring intellectual capital (Goh, 2005). Some of them are the balanced scorecard developed by Kaplan and Norton in 1992, the Skandia navigator developed by Edivisson in 1994, the technology broker by Brooking in 1996, the intellectual capital index developed by Roos in 1997, the intangible asset monitor developed by Sveiby, (1997), the economic value added (EVA) by Stewart in 1997, the Value added intellectual capital $\left(\mathrm{VAIC}^{\mathrm{TM}}\right)$ developed by Pulic in 1997.

Over the years, there has been a large body of empirical research concerning the impact of IC on firms' performance with respect to various industries in both developed and developing countries. Empirical research on testing the relation between IC and firms' performance has produce mixed results (For instance; Bontis et al., 2000; Abernathy et al., 2003; Bollen et al., 2005; Cohen and Kaimenakis, 2007; Mavridis, 2004; Chen et al., 2005; Shiu, 2006a; Ghosh and Wu, 2007; Tan et al., 2007; Chan, 2009a,; Ting and Lean, 2009; Zeghal and Maaloul, 2010; Maditinos et al., 2011) Find positive impact of IC on the firms' performance. On the other hand, some researches find negative relationship between IC and firms' performance (see. Firer and Williams, 2003; Shiu, 2006b; Chan, 2009b). While, Williams, 2001; Appuhami, 2007; Ting and Lean, 2009 does not find a significant relationship between IC and firm performance. 
The empirical examination of the IC and firms' performance is particularly important in banking sector because the banking sector is a knowledge-intensive sector (Mavridis, 2004). Acting as a financial intermediately, banks provide essential service in stimulating economic growth (Goh, 2005).

To the best of the authors' knowledge, there is limited empirical studies, if not none, are available in the context of looking the role of IC for the Islamic banks. Given Indonesia and Malaysia has experienced rapid development in Islamic banking industry, researches concerning the development of Islamic banks in the aspect of Intellectual capital is very timely. This is the aim of this paper.

Islamic banking which has been in existence to be the alternative of conventional banking system is relatively a new concept in both countries. The first Islamic bank in Malaysia was established in early 80ies while in Indonesia, it was established in early 90ies. Compare to the existence of conventional banks in both countries, these Islamic banking concept can be categorized as a new concept.

While the current focus on the development is on the IC and at the same time, Islamic banking concept gain momentum in this current modern era. It is timely to investigate the development of intellectual capital in Islamic banks in Indonesia and Malaysia. These countries have been adopted as these have shown a well-documented data for our purpose of study. While our main concern is to look into the significance of IC to Islamic bank, in addition to that, this study also examined how the intellectual capital efficiency affects the performance of Islamic banks in both countries.

The structure of this paper is as follows. The following section describes background of the Islamic banking industry in Indonesia and Malaysia. Following it, discuss the hypothesis development and explains the data and empirical framework. Next is to discuss the estimation results and ended with the conclusion. 


\section{LITERATURE REVIEW}

\section{Islamic Banks In Indonesia And Malaysia}

Although the Muslim population in Indonesia reaches more than $70 \%$, the establishment of Islamic banks was relatively late as compared to the neighboring country, Malaysia. The first Islamic bank namely Bank Muamalat Indonesia (BMI), which was established in November 1 1991, was highly supported by the then President of Indonesia, Suharto. Up to the 2008, Indonesia, unlike Malaysia, had not had an Islamic Banking Act. The existing Islamic banks are under the revision of the conventional banking act which mentions that the banks have been allowed to operate other types of banking system which does not use interest.

Bank Muamalat performed good in the early years of its commencement. In the second year of its existence, deposit increased from 20,800 million Rupiah in 1992 to 60,320 million in 1993. Similarly, financing also increased very significantly, from 32,650 million Rupiah to 92,000 million Rupiah in the subsequent year (Table 1). The following years, BMI was able to maintain good performance. However, the Asian crisis in 1997 created damage to the banking system. Not only did the conventional banks suffer, Islamic Banks were also affected. Table 1show that in 1998, Islamic banking assets, financing and deposit were declining very significantly. Growth of those three indicators shows contractions of $18.3 \%, 30.5 \%$, and $15.4 \%$ respectively.

At that time, Bank Indonesia had to increase the interest rate in a significant rate to prevent further deterioration of the Rupiah due to capital flight. Consequently, this high interest rate caused the withdrawal of funds from the Islamic banks to conventional banks. This kind of situation known as the displacement commercial risk had to be faced by Islamic banks. It is the risk whereby depositors withdraw their money from Islamic banks and put it in the conventional banks due to more attractive interest rates given by their conventional counterparts. Nevertheless, in 1999, Islamic banks were able to recover. Asset, Financing and Deposit increased to $44.5 \%, 8.05 \%$ and $34.7 \%$ respectively. 
The growth of Islamic banks in Indonesia, although increased significantly in the nominal term, did not increase in terms of the percentage share of the total banking asset. In 2000, total Islamic banking assets amounted to IDR 1,790,168 million and that amount accounted for only $0.17 \%$ of total banking assets. 2004 marked the year in which the proportion of Islamic banking assets out of total banking assets reached beyond $1 \%$ (Islamic Banking Statistics, August 2004). In 2011, the asset, financing as well as deposit reach to $145,467,000,102,655,000$ and 115,415 million rupiah respectively. Moderate growth has been shown in 2012 whereby asset, financing and deposit shows $34.65 \%, 45.8 \%, 27.81$.

Meanwhile, Islamic finance concept to be introduced in Malaysia was fully supported by the government. Islamic banks were not the first institution to offer Islamic financial instruments in Malaysia. There exists another institution which offers Islamic financial instrument namely Tabung Haji (TH). TH was commanded to collect and mobilize savings along with Islamic principles for those who intend to perform Pilgrimage (Hajj). Only after the Islamic Banking Act was established in 1983, Islamic Banks could then be established. As mentioned earlier, the first Islamic bank in Malaysia i.e Bank Islam Malaysia Berhad (BIMB) was established on March 1, 1983 where the operation started on July 1, 1983. The initial capital was about RM580 million which consisted of authorized capital of RM 100 million and paid up capital of RM80 million. The Malaysian government, Tabung Haji, various religious councils and agencies had also contributed to that initial capital (Ariff, 1989).

Table 1

Performance of Islamic Banks in Indonesia

\begin{tabular}{|c|c|c|c|c|c|c|}
\hline \multirow{2}{*}{ Year } & Asset $^{\mathrm{a}}$ & Financing $^{\mathrm{b}}$ & \multirow{2}{*}{ Deposit $^{\mathrm{c}}$} & \multicolumn{3}{|c|}{ Growth (\%) } \\
\cline { 5 - 7 } & & & & Asset & Financing & Deposit \\
\hline 1992 & 120,880 & 32,560 & 20,800 & & & \\
\hline 1993 & 166,960 & 92,000 & 60,320 & 38.12 & 182.56 & 190.00 \\
\hline 1994 & 246,080 & 188,800 & 132,880 & 47.39 & 105.22 & 120.29 \\
\hline 1995 & 394,400 & 285,920 & 275,680 & 60.27 & 51.44 & 107.47 \\
\hline 1996 & 515,200 & 310,480 & 396,560 & 30.63 & 8.59 & 43.85 \\
\hline
\end{tabular}


Iqtishadia, Vol. 9, No. 2, 2016

\begin{tabular}{|c|c|c|c|c|c|c|}
\hline 1997 & 586,720 & 456,160 & 463,440 & 13.88 & 46.92 & 16.87 \\
\hline 1998 & 479,200 & 317,040 & 391,920 & -18.33 & -30.50 & -15.43 \\
\hline 1999 & 692,800 & 342,560 & 528,080 & 44.57 & 8.05 & 34.74 \\
\hline 2000 & $1,790,168$ & $1,271,162$ & $1,028,923$ & 158.40 & 271.08 & 94.84 \\
\hline 2001 & $2,718,770$ & $2,049,793$ & $1,806,366$ & 51.87 & 61.25 & 75.56 \\
\hline 2002 & $4,045,235$ & $3,276,650$ & $2,917,726$ & 48.79 & 59.85 & 61.52 \\
\hline 2003 & $7,858,918$ & $5,530,167$ & $5,724,909$ & 94.28 & 68.78 & 96.21 \\
\hline 2004 & $15,325,997$ & $11,489,933$ & $11,862,117$ & 95.01 & 107.77 & 107.20 \\
\hline 2005 & $20,879,874$ & $15,231,942$ & $15,582,329$ & 36.24 & 32.57 & 31.36 \\
\hline 2006 & $26,722,030$ & $20,444,907$ & $20,672,181$ & 27.98 & 34.22 & 32.66 \\
\hline 2007 & $36,537,637$ & $27,944,311$ & $28,011,670$ & 36.73 & 36.68 & 35.50 \\
\hline 2008 & $49,555,122$ & $38,194,974$ & $36,852,148$ & 35.6 & 36.68 & 31.55 \\
\hline 2009 & $66,090,000$ & $46,886,000$ & $52,271,000$ & 33.37 & 22.75 & 41.84 \\
\hline 2010 & $97,519,000$ & $68,181,000$ & $76,036,000$ & 47.55 & 45.42 & 45.46 \\
\hline 2011 & $145,467,000$ & $102,655,000$ & $115,415,000$ & 49.17 & 50.56 & 51.79 \\
\hline 2012 & $195,871,000$ & $149,672,000$ & $147,512,000$ & 34.65 & 45.8 & 27.81 \\
\hline 2013 & $242,276,000$ & $184,122,000$ & $183,534,000$ & 23.69 & 23.02 & 24.42 \\
\hline 2014 & $272,343,000$ & $199,330,000$ & $217,858,000$ & 12.41 & 8.26 & 18.70 \\
\hline 2015 & $272,389,000$ & $203,894,000$ & $215,339,000$ & 0.02 & 2.29 & -1.16 \\
\hline$N 010$. & 9 & & & & \\
\hline
\end{tabular}

Note. ${ }^{\mathrm{a}}, \mathrm{b}, \mathrm{c}$ are in Million IDR

Source: Bank Indonesia Shariah Banking Statistics, Various Issues and Harahap and Basri (2003)

IBA specifies that Islamic banks also have to follow the supervision and regulation by Bank Negara Malaysia. In addition, the bank should also adhere to Sharia rules. In the initial few years, BIMB had shown a remarkable performance. After three years in operation, 1987, BIMB ranked twelfth among twenty three locally incorporated commercial banks in terms of both assets and deposits. On the shareholders' funds, it ranked ninth (Ariff,1989).

In terms of the number of Islamic bank institutions, Table 2 shows that since its commencement to 1998, there was only one full-fledged bank, namely Bank Islam Malaysia Berhad (BIMB). In 1999, the second Islamic bank was established, namely Bank Muamalat Malaysia Berhad (BMMB). It arose from the merger between Bank Bumiputera Malaysia Berhad (BBMB) and Bank of Commerce Berhad (BOCB). The bank commenced operations on 1 October 1999 (BNM Annual Report, 1999). This second full-fledged Islamic bank is expected 
to play a key role to foster an active and progressive Islamic Banking system.

Table 2 shows that assets increased from time to time, although in 1984, 1987 and 1991, it experienced negative growth. The rates of total assets were $-11.9 \%,-14.7 \%,-1.8 \%$ respectively. In 1986, BIMB total assets increased more than $100 \%$. During the period of positive growth, assets grew between $19-21 \%$ in 1988, 1989, 1992, and 1993. For the first ten years, the policy of the government was to give monopoly status to BIMB. This meant that the government did not allow any other Islamic banks to operate competitively with BIMB. The intention of this policy was to study, and to evaluate the experience of BIMB.

Table 2

Performance of Islamic Banks in Malaysia

\begin{tabular}{|r|c|c|r|r|r|r|}
\hline Year & T. Assets $^{\mathrm{a}}$ & T. Deposits $^{\mathrm{b}}$ & T. Financing $^{\mathrm{c}}$ & \multicolumn{3}{|c|}{ Annual Changes $(\%)$} \\
\hline 1983 & 370 & 274 & \multicolumn{1}{c|}{250} & \multicolumn{1}{c|}{ Asset } & \multicolumn{1}{c|}{ Deposit } & Financing \\
\hline 1984 & 326 & 241 & 161 & -11.9 & -12.0 & -35.6 \\
\hline 1985 & 514 & 410 & 392 & 57.7 & 70.1 & 143.5 \\
\hline 1986 & 1093 & 967 & 525 & 112.6 & 135.9 & 33.9 \\
\hline 1987 & 932 & 809 & 429 & -14.7 & -16.3 & -18.3 \\
\hline 1988 & 1134 & 1022 & 610 & 21.7 & 26.3 & 42.2 \\
\hline 1989 & 1368 & 1229 & 666 & 20.6 & 20.3 & 9.2 \\
\hline 1990 & 1426 & 1221 & 817 & 4.2 & -0.7 & 22.7 \\
\hline 1991 & 1400 & 1175 & 808 & -1.8 & -3.8 & -1.1 \\
\hline 1992 & 1676 & 1323 & 1028 & 19.7 & 12.6 & 27.2 \\
\hline 1993 & 2009 & 2259 & 1065 & 19.9 & 70.7 & 3.6 \\
\hline 1994 & 4885 & 4655 & 1737 & 143.2 & 106.1 & 63.1 \\
\hline 1995 & 6197 & 4926 & 3492 & 26.86 & 5.82 & 101.04 \\
\hline 1996 & 10133 & 7264 & 6143 & 63.51 & 47.46 & 75.92 \\
\hline 1997 & 17881 & 10330 & 10750 & 76.46 & 42.21 & 75.00 \\
\hline 1998 & 21632 & 16432 & 10943 & 20.98 & 59.07 & 1.80 \\
\hline 1999 & 36136 & 24804 & 13724 & 67.05 & 50.95 & 25.41 \\
\hline 2000 & 47068 & 35923 & 20891 & 30.25 & 44.83 & 52.22 \\
\hline 2001 & 58929 & 47106 & 28201 & 25.20 & 31.13 & 34.99 \\
\hline 2002 & 68070 & 53306 & 36718 & 15.51 & 13.16 & 30.20 \\
\hline 2003 & 82196 & 60212 & 48615 & 20.75 & 12.96 & 32.40 \\
\hline 2004 & 94580 & 72859 & 57883 & 15.07 & 21.00 & 19.06 \\
\hline
\end{tabular}




\begin{tabular}{|c|c|c|c|c|c|r|}
\hline 2005 & 111823.5 & 83874.8 & 67364.6 & 18.23 & 15.12 & 16.38 \\
\hline 2006 & 133031 & 99181 & 78513 & 18.96 & 18.24 & 16.55 \\
\hline 2007 & 157125 & 121975 & 89857 & 18.11 & 22.98 & 14.44 \\
\hline 2008 & 192682.3 & 154701.9 & 107721.8 & 22.63 & 26.83 & 19.88 \\
\hline 2009 & 233656.3 & 188839.4 & 134973.5 & 21.27 & 22.07 & 25.30 \\
\hline 2010 & 267602.9 & 216952.5 & 162081.6 & 14.53 & 14.89 & 20.08 \\
\hline 2011 & 334982.6 & 266387.1 & 200295.8 & 25.18 & 22.79 & 23.58 \\
\hline 2012 & 381544.3 & 306456.5 & 236623.9 & 13.90 & 15.04 & 18.14 \\
\hline 2013 & 426641.5 & 348946.5 & 277919.6 & 11.82 & 13.86 & 17.45 \\
\hline 2014 & 477055.6 & 400679.9 & 330174.4 & 11.82 & 14.83 & 18.80 \\
\hline 2015 & 535349.7 & 402660.6 & 384443.9 & 12.22 & 0.49 & 16.44 \\
\hline
\end{tabular}

Sources : BIMB Annual Report and BNM Monthly

Report, Various Issues

In 1993, Skim Perbankan Tanpa Faedah (SPTF), was introduced. It was a policy which allowed conventional banks to offer Islamic banking products. Unlike BIMB which is a fullfledged Islamic bank, and hence regulated by IBA 1983, these conditional banks (banks which offer Islamic banking product) are regulated by BAFIA. The introduction of SPTF marked the significant growth of the Islamic banking assets in the following years, It doubled from initially RM2009 million in 1993 to RM4,885 million in the subsequent year (it increased up to $143.16 \%$ ). Similarly, deposits and financing also increased. In 1993, total deposit and financing were RM2,259 million and RM1,065 million respectively whereas in the following year, deposits and financing jumped to RM 4,655,000 and RM $1,737,000$ respectively. This remarkable growth, at that time, was partly contributed by sustained and rapid economic growth. This buoyant economy provided a strong foundation for Islamic banking institution to accelerate its development.

However, this strong and significant growth was interrupted by the Asian crisis which occurred in 1997. At the time of the crisis, BNM raised the three month intervention rate from $10 \%$ to $11 \%$ (Mahani, 2000). Under the rising interest rates, customers began to confiscate the opportunity to lock in their cost of long term financing under Islamic property financing which was cheaper as compared to conventional financing over 
the long-run (BNM Annual Report 1997). As a result, Islamic banks faced a liquidity problem. This was so, since $90 \%$ of the financing were in the form of MurÉbaÍah, BaiBithamanAjil, and Al IjÉrahThumma Al-Bai'. Unlike conventional banks which had flexibility to adjust upward the interest rates on borrowing,Islamic banks could not react promptly under those types of contract. As a result, Islamic Banks had to borrow from the Islamic money market which amounted to RM 2.6 Billion (BNM Annual Report, 1997). Nevertheless, significant growth was achieved after the crisis, as shown in Table 2.

\section{HYPOTHESIS DEVELOPMENT}

Research on intellectual capital has received a lot of attention in the accounting literature (eg Firer and Williams, 2003; Chen et al., 2005; Shiu, 2006a, b; Tan et al., 2007; Chan, 2009a, b; Ting and Lean, 2009; Zeghal and Maaloul, 2010; Maditinos et al., 2011). One stream literature focuses on the impact of knowledge assets in generating sustainable competitive advantage necessary for the creation of superior business performance (Barney1991). Intellectual capital as combination of human capital, structural capital, and relational capital skill is considered as the key resource for firm's competitiveness and prosperity (Bontis, 2001; Bontis and Fitzenz, 2002; Huselid et al., 1997; Lado and Wilson, 1994). The important role of IC as perceived by them needs to be investigated in order to capture the contribution of IC components, human capital, structural capital, and relational capital in value creation represented by corporate conventional financial performance.

This research explores this issue empirically by examining the relationship between a relevant measure of IC as proposed by Pulic, (1998) and Islamic Bank performance as measured by ROA and ROE which represents profitability and productivity. Thus, in this research we expect a positive relationship between financial performance and the IC performance of Islamic bank. Hence our hypothesis is:

H1. The higher the performance of Islamic banks' IC, the better will be the Islamic banks' financial performance. 


\section{DATA AND METHODOLOGY}

In an attempt to examine the linkage between capitals employed human capital and structural capital as a measure of intellectual capital and Islamic banking performance. The data collected are pooled data that being arrange in time series dimension. These annual data are collected from 2010 to 2014. In the first step we employ independent sample $t$ test to compare the development of intellectual capital in Islamic banking between Indonesia and Malaysia. In order to investigate the impact of value added intellectual capital component to Islamic banks' performance, the ordinary least square (OLS) regression are employed. The model to be estimated is thus:

Model 1:

$$
\begin{aligned}
R O A_{i, t}=\beta_{0}+ & \beta_{1} V A H U_{i, t}+\beta_{2} S T V A_{i, t}+\beta_{3} V A C A_{i, t} \\
& +\beta_{4} F D R_{i, t}+\beta_{5} S I Z E_{i, t}+\varepsilon_{i, t}
\end{aligned}
$$

Model 2:

$$
\begin{aligned}
R O E_{i, t}=\gamma_{0}+ & \gamma_{1} V A H U_{i, t}+\gamma_{2} S T V A_{i, t}+\gamma_{3} V A C A_{i, t}+\gamma_{4} F D R_{i, t} \\
& +\gamma_{5} S I Z E_{i, t}+\varepsilon_{i, t}
\end{aligned}
$$

\section{The dependent variables}

A number of accounting bases measure have been utilized by the researchers representing financial performance of the firm, namely, profitability (ROA and ROE) and productivity (ATO) (Firer and Williams, 2003; Chen et al., 2005). For this purpose, this study employs two dependent variables, namely, ROA and ROE. Return on Assets (ROA) is the ratio of pre-tax income divided by average total assets as reported in the annual report. ROA reflects banks 'efficiency in utilizing total assets. This can be an indicator of profitability as well as indicator of bank's performance. The Return on Equity (ROE) is the after tax profit divided by book value of equity. It represents the ultimate measure of how well the companies serve the economic interest of their shareholders'. 


\section{The explanatory variables}

Value added intellectual capital $\left(\mathrm{VAIC}^{\mathrm{TM}}\right.$ ) introduced by Pulic (1998) as a measurement of the intangible asset efficiency. Firms with a higher VAIC $^{\mathrm{TM}}$ score indicate that they have a highervalue creation in utilizing all available resource, namely, Intellectual capital, Human capital, structural capital and physical capital. VAIC ${ }^{\mathrm{TM}}$ used financial statements of the firm to measure the performance of individual companies. VAIC ${ }^{\mathrm{TM}}$ of a firm can be calculated using the following steps:

Value added (VA): Newly created value, calculated for an institution during a particular fiscal year as:

$$
V A_{i}=\text { OUTPUT }_{i}-\text { INPUT }_{i}
$$

where OUTPUT $=$ total income from all products and services sold during the particular fiscal year. And IN-PUT = The total costs and expenses that incurred by the firm during that particular fiscal year (excluding labor expenses, which are employees' compensation and all expenses that are related to their training and development. In this analysis, labor expenses is considered an investment and not cost.

Structural Capital (SC) is defined as result of Human Capital's past performance (organization, licenses, patents, image, standards, and relationship with customers). According to Pullic, (1998) there is a proportionate inverse relationship between HC and $\mathrm{SC}$ in the value creation process, the less $\mathrm{HC}$ contributes in value creation process the more $\mathrm{SC}$ is involved. And it is calculated as:

$$
S C_{i}=V A_{i}-H C_{i}
$$

where HC (Human Capital) = overall employees' compensations and all expenses that are related to their training and development.

The first element of VAIC ${ }^{\mathrm{TM}}$ is Value Added Human Capital (VAHU)which shows how much VA is created on each 
monetary unit invested in HC. Pullic, (1998) suggest the following formula in estimating VAHU:

$$
V A H U_{i}=V A_{i} / H C_{i}
$$

The second element of $\mathrm{VAIC}^{\mathrm{TM}}$ is Value added Structural Capital (STVA) as an indicator that shows the contribution of SC in value creation process. As argued by Pullic, (1998) there is inverse relationship between $\mathrm{HC}$ and $\mathrm{SC}$ in value creation process, he suggests the following formula for calculating structural efficiency:

$$
S T V A_{i}=S C_{i} / V A_{i}
$$

Furthermore, we can calculate Intellectual Capital Efficiency (ICE) as indicator of human capital and structural capital contribution in value creation process. In other words, IC represents the intangible asset contributions on firms' value. ICE is calculated as follows.

$$
I C E_{i}=V A H U_{i}+S T V A_{i}
$$

The third element of $\mathrm{VAIC}^{\mathrm{TM}}$ is theValue Added Capital Employed (VACA), an indicator that shows how much VA is created on each monetary unit invested in capital employed (CE) as representation of firms' physical and financial assets .

$$
V A C A_{i}=V A_{i} / C E_{i}
$$

where $\mathrm{CE}($ Capital Employed $)=$ book value of the net assets for firm.

Based on the three indicators, namely, VAHU, STVA, and VACA as discussed above, we can estimate the Value Added Intellectual Coefficient $\left(\mathrm{VAIC}^{\mathrm{TM}}\right)$ that indicates the value creation efficiency of all resources (sum of the previous indicators). 


$$
V A I C^{T M}=I C E_{i}+V A C A_{i}
$$

In these models we also employ two control variables namely, financing to deposit ratio (FDR) as measured by total financing divide by total deposit, and size measured by natural logarithm of total asset.

\section{EMPIRICAL RESULTS AND ANALYSIS}

\section{a. Independent sample t-test}

Table 3 presents the VAHU, STVA, VACA, and $\mathrm{VAIC}^{\mathrm{TM}}$ scores of the Islamic banking for Indonesia and Malaysia. The results from the VAHU indicate that Islamic banking in Indonesia and Malaysia has exhibited a mean of 1.6247 and 5.9067 respectively during period under study. The empirical finding suggest that the Malaysian banking has performed relatively well in its human capital performance. The STVA scores show consistent results where Islamic banks in Malaysian has better efficiency score as compare to Indonesia. STVA represent the competitive intelligence, formulas, information system, policies, processes, that result from the products or systems the firm has created over time. However, in term of tangible asset efficiency as measured using VACA, Islamic banks in Indonesia seem to have a better efficiency score. Capital employed represents the value of the assets that contribute to a firm's ability to generate revenue. Furthermore, overall efficiency score represented by VAIC ${ }^{\mathrm{TM}}$ exhibit mean of 2.1416 for Indonesia and 6.5572 for Malaysia. Moreover, the results from the independent sample t-test also suggest that there are significant different in VAHU, STVA, VACA, and VAIC ${ }^{\mathrm{TM}}$ scores between Islamic banks in Indonesia and Malaysia. This result suggests that Islamic banks in Malaysia have a better performance in developing its Intellectual capital.

Islamic banks in Malaysia which have been shown to have a better human capital performance as compare to that in Indonesia is already expected. Many facts have been supporting and explaining this result. At least two factual things which may be the reasons; first Malaysia has more experience in the Islamic banking industry due to 10 years earlier implementation of this 
industry. Certainly with this advantage, Malaysia can make regular and consistent evaluation on the performance of their Islamic banking industry as compare to that of Indonesia. This evaluation is important as a basis for a better performance on the following years. Secondly, level of government support is different between these two countries. Given the fact that Malaysia claim to be Islamic country, it is easier for Malaysia to design a proper education on Islamic banking to universities. The collaboration from the Islamic banking practitioners and the Islamic banking researchers in the universities lead to the knowledge extension in a much faster way. If this knowledge is transferred to the students and society then direct or indirectly, it will influence the performance of Islamic banking industry in this country.

Table 3

Value Added Intellectual Capital Components

\begin{tabular}{llcccc}
\hline \multirow{2}{*}{ Islamic Bank } & Descriptive & VAHU & STVA & VACA & VAIC \\
& Statistics & & & & \\
\hline \multirow{2}{*}{ Indonesia } & Mean & 1.6247 & 0.4834 & 0.0335 & 2.1416 \\
& Std. Dev. & 0.6547 & 0.7785 & 0.0177 & 0.8375 \\
& Maximum & 3.8475 & 4.9334 & 0.0797 & 4.6745 \\
& Minimum & -0.2542 & 0.0523 & -0.0046 & 1.1360 \\
\hline \multirow{2}{*}{ Malaysia } & Mean & 5.9067 & 0.6367 & 0.0136 & 6.5572 \\
& Std. Dev. & 8.3424 & 0.4188 & 0.0105 & 8.4950 \\
& Maximum & 35.3898 & 2.7264 & 0.0321 & 36.3818 \\
& Minimum & -6.1235 & -0.5597 & -0.0532 & -5.0133 \\
\hline \multirow{2}{*}{ Independent } & Equal var. & & & & \\
& Eqsumed & $-3.068 * *$ & -1.321 & $7.216 * * *$ & $-3.104 * *$ \\
& Equal var. not & & & & - \\
& assumed & $-4.269 * * *$ & -1.102 & $6.174 * * *$ & $4.305 * * *$ \\
& & & & & \\
\hline
\end{tabular}

Note: $* * *, * *$ and $*$ denote significance at 1 percent, 5 percent and 10 percent level respectively. 


\section{b. Regression model}

The regression results focusing on the relationship between Islamic banks performance and the Intellectual Capital components are represents in Table 4. The equations are based on pooled data observation during the 2010-2014 periods. Several general comments regarding the test results are warranted. First, the model performs reasonably well with most variables remain stable across the various regressions tested. And second, the explanatory power of the models is also reasonably high, while the F-statistics is significant at the 1 percent level for all regression models.

Table 4

Regression test results

\begin{tabular}{|c|c|c|c|c|}
\hline \multirow{2}{*}{$\begin{array}{l}\text { Independent } \\
\text { Variable }\end{array}$} & \multicolumn{2}{|c|}{ Indonesia } & \multicolumn{2}{|c|}{ Malaysia } \\
\hline & ROA & ROE & ROA & ROE \\
\hline $\mathbf{C}$ & $\begin{array}{c}-0.0073 * * * \\
(-2.874)\end{array}$ & $\begin{array}{l}-0.134 * \\
(-2.030)\end{array}$ & $\begin{array}{c}-0.00005 \\
(-0.013)\end{array}$ & $\begin{array}{c}-0.006 \\
(-0.081)\end{array}$ \\
\hline VAHU & $\begin{array}{c}0.0075 * * * \\
(13.923)\end{array}$ & $\begin{array}{c}0.0315 * * \\
(2.243)\end{array}$ & $\begin{array}{c}0.00022 * * * \\
(5.732)\end{array}$ & $\begin{array}{c}0.003 * * * \\
(4.511)\end{array}$ \\
\hline STVA & $\begin{array}{c}-0.00059 \\
(-1.192)\end{array}$ & $\begin{array}{l}0.0139 \\
(1.068)\end{array}$ & $\begin{array}{l}0.0013 \\
(1.617)\end{array}$ & $\begin{array}{l}0.036 * * \\
(2.480)\end{array}$ \\
\hline VACA & $\begin{array}{l}0.2208 * \\
(10.320)\end{array}$ & $\begin{array}{c}3.0103 * * * \\
(5.395)\end{array}$ & $\begin{array}{c}0.6172 * * * \\
(22.072)\end{array}$ & $\begin{array}{c}5.215 * * * \\
(9.349)\end{array}$ \\
\hline FDR & $\begin{array}{c}-0.0052 * * \\
(-2.630)\end{array}$ & $\begin{array}{l}0.3771 \\
(0.736)\end{array}$ & $\begin{array}{c}0.001 \\
(0.861)\end{array}$ & $\begin{array}{c}-0.022 \\
(-1.126)\end{array}$ \\
\hline SIZE & $\begin{array}{c}0.00064 \\
(0.781)\end{array}$ & $\begin{array}{l}0.0022 \\
(1.050)\end{array}$ & $\begin{array}{c}0.000 \\
(-1.822)\end{array}$ & $\begin{array}{c}0.000 \\
(-0.002)\end{array}$ \\
\hline R-Square & 0.944 & 0.599 & 0.923 & 0.740 \\
\hline $\begin{array}{l}\text { Adj R- } \\
\text { Square }\end{array}$ & 0.934 & 0.532 & 0.917 & 0.720 \\
\hline F-Statistic & 100.367 & 8.954 & 154.194 & 36.407 \\
\hline Durbin & 1.717 & 1.022 & 1.034 & 0.983 \\
\hline
\end{tabular}


Watson

Note: Number in parentheses are t-statistics. ***,** and * denote significance at 1 percent, 5 percent and 10 percent level respectively.

Referring to the impact of human capital efficiency, VAHU is positively related to the Islamic banks performance both Indonesia and Malaysia. The findings imply that banks with higher human capital efficiency tend to exhibit higher ROA and ROE. VAHU measure the employee competence in creating both tangible and intangible assets by contributing in the continues generation of knowledge and ideas. These results is consistent with the reserachs conducted by (Mondal and Ghosh, 2012; Hatch and Dyer, 2004; Hitt et al., 2001; Liu et al., 2009; Petty and Guthrie, 2000). These findings also suggest that in order to accelerate the Islamic banking growth both in Indonesia and Malaysia, stakeholder should focus on human capital development instead of physical assets. In essence, financial sector especially banks, need a generation of professional executives who are more costumer centric, technology savvy, highly qualified, flexible and agile with comprehensive skill sets. In the context of globalization, high-class human capital has become a necessity and not merely opulence.

Concerning the impact of structural capital efficiency, STVA has no impact on the Islamic banking banks performance both Indonesia and Malaysia. These results imply that profitability of Islamic banks is not related with its structural capital. This capital is resulted from the products or system that firm has created over time and will remain with the enterprise when people leave. Hence, firms that possess strong structural capital will have supportive culture that encourages their employee to learn and practice new things. Mondal and Ghosh, (2012) also find the insignificant impact of structural capital on banks' performance in India. Moreover, in the same study Goh, (2005) find that the performance of human capital is higher than structural capital for Malaysian case.

Capital efficiency as measured by VACA is positively related to Islamic banks performance in Indonesia and Malaysia. 
Capital employed represents the effectiveness of the firm's tangible asset to generate revenue. The higher value of VACA means that firm's asset has higher productivity in generating income. The results suggest that banks with higher asset efficiency tend to exhibit higher profitability. Furthermore, from the coefficient of the VACA in the regression model we can see that VACA has higher coefficient level rather than VAHU both for Indonesia and Malaysia. These findings suggest that during the period under study, the development of Islamic banks in Indonesia and Malaysia still relay on physical asset development. Hence, Islamic banks should also focus on development in tangible asset, since the banking sector is one of the sectors that utilize intensive intellectual capital specially on knowledgeintensive sector (Mavridis,2004).

\section{CONCLUSION}

This paper attempts to empirically analyze the Intellectual Capital (IC) of the Islamic banks in Indonesia and Malaysiaduring the periode of 2010 to 2014. The Intellectual capital efficiency estimation of individual banks are evaluated by using the VAIC ${ }^{\mathrm{TM}}$ approach. The analysis is confined to the universe of the Islamic banks that have been operating in Indonesia and Malaysia. During the period under study, the empirical findings indicate that the Islamic Banks in Malaysia have exhibited better efficiency levels as compare to the Islamic banks in Indonesia.

The results from the multivariate regression analysis suggest that the relatively better human capital efficiency tend to exhibit higher profitability levels. Moreover, Structural capital is not related to Islamic bank performance. The results also suggets that capital efficiency tend to exhibit higher profitability levels both in Indonesia and Malaysia. Among the three components of $\mathrm{VAIC}^{\mathrm{TM}}$ physical capital has higher contributions on Islamic banks' performance as compare to human capital and structural capital.

Despite these limitations, the findings of this study are expected to contribute significantly to the existing knowledge on the operating performance of the Islamicbanking sector. 
Nevertheless, the study has also provided further insight to the bank's specific management as well as the policymakers with regard to attaining optimal utilization of capacities, improvement in managerial expertise, efficient allocation ofscarce resources, and the most productive scale of operation of the Islamic banks in Indonesia and Malaysia.

\section{REFERENCES}

Abarnethy, M. P., Bello, A. D., Labory, S. Lev, B., Wyatt, A., \& Zambon, A. (2003). Study on the measurement of intangible assets and associated reporting practices.Commission of the European Communities Enterprise Directorate General.

AmitavaMondal, Santanu Kumar Ghosh. (2012). Intellectual capital and financial performance of Indian banks.Journal of Intellectual Capital,13(4), 515 - 530.

Andriessen, D. (2004). IC valuation and measurement: classifying the state of the art.Journalof Intellectual Capital, 5(4), 230-42.

Appuhami, R. (2007). The impact of intellectual capital on investors' capital gains on shares: anempirical investigation of Thai banking, finance \& insurance sector.InternationalManagement Review, 3(2), 14-25.

Arif, Mohammad. (1989). Islamic Banking in Malaysia: Framework, performance and lesson. Journal of IslamicEconomics, 2(2).

Bechtel, R. (2007). Calculating human capital: the market based valuation of the humanresource.German Journal of Human Resource Research, 21(3), 206-31.

Barney, J.B. (1991). Firm resources and sustainable competitive advantage. Journal ofManagement, 17(1), 99-120.

Bontis, N. (2001). Assessing knowledge assets: a review of the models used to measureintellectual capital.International Journal of Management Reviews, 3(1), 41-60.

Bontis, N. and Fitz-enz, J. (2002). Intellectual Capital ROI: a causal map of human capitalantecedents and consequents. Journal of Intellectual Capital, 3(3), 223-47. 
Bontis, N., Keow, W.C. and Richardson, S. (2000). Intellectual capital and business performance in Malaysian industries.Journal of Intellectual Capital, 1(1), 85-100.

Bollen, L., Vergauwen, P. and Schnieders, S. (2005). Linking intellectual capital and intellectualproperty to company performance.Management Decision, 43(9), 1161-85.

Chan, K.H. (2009a). Impact of intellectual capital on organisational performance. An empiricalstudy of companies in the Hang Seng Index (Part 1).The Learning Organization, 16(1), 4-21.

Chan, K.H. (2009b). Impact of intellectual capital on organisational performance. An empiricalstudy of companies in the Hang Seng Index (Part 2).The Learning Organization, 16(1), 22-39.

Chen, M., C., Cheng, S., J (2005). An empirical investigation of the relationship between intellectual capital and financial performance.Journal of Intellectual Capital, 6(2),159-176.

Cohen, S. and Kaimenakis, N. (2007). Intellectual capital and corporate performance inknowledge-intensive SMEs.The Learning Organization, 14(3), 241-62.

Dimitrios G. Mavridis, (2004). The intellectual capital performance of the Japanese banking sector.Journal of Intellectual Capital, 5(1), 92 - 115.

Firer, S. and Williams, S.M. (2003). Intellectual capital and traditional measures of corporateperformance.Journal of Intellectual Capital, 4 (3), 348-60.

Ghosh, D. \&, Wu, A. (2007). Intellectual capital and capital markets: additional evidence.Journal of Intellectual Capital, 8(2), 216 - 235.

Goh, P. C. (2005). Intellectual capital performance of commercial banks in Malaysia. Journal of Intellectual Capital, 6(3), 385 - 396.

Hatch, N.W. and Dyer, J.H. (2004). Human capital and learning as a source ofsustainable competitive advantage.Strategic Management Journal, 25(12),1155-78.

Hitt, M.A., Bierman, L., Shimizu, K. and Kochhar, R. (2001). Direct and moderating effects ofhuman capital on strategy and performance in professional service firms: a resourcebasedperspective.The Academy of Management Journal, 44(1), 13-28. 
Huselid, M.A., Jackson, S.E. and Schuler, R.S. (1997). Technical and strategic human resourcemanagement effectiveness as determinants of firm performance.The Academy ofManagement Journal, 40(1), 171-88.

Lado, A.A. and Wilson, M.C. (1994). Human resource systems and sustained competitiveadvantage: a competency-based perspective.The Academy of Management Review,19(4), 699-727.

Liu, D.-Y., Tseng, K.-A. and Yen, S.-W. (2009). The incremental impact of intellectual capital onvalue creation.Journal of Intellectual Capital, 10(2), 260-76.

Maditinos, D., Chatzoudes, D., Tsairidis, C. and Theriou, G. (2011). The impact of intellectualcapital on firms' market value and financial performance.Journal of Intellectual Capital,12(1), 132-51.

Mahani, (2000). Implications of the Malaysian Experience on Future International Financial Arrangements,' Special Focus on The Asian Financial Crisis: Hindsight, Insight, Foresight. ASEAN Economic Bulletin, 17(2), August 2000

Mavridis, D. (2004). The intellectual capital performance of the Japanese banking sector. Journal of Intellectual Capital, 5(1), 92-115.

Mondal, A., Ghosh, S., K. (2012) -Intellectual capital and financial performance of Indian banks. Journal of Intellectual Capital, 13(4), 515-530.

Moon, Y.J. and Kym, H.G. (2006). A model for the value of intellectual capital. Canadian Journalof Administrative Sciences, 23(3), 253-69.

Petty, R. and Guthrie, J. (2000). Intellectual capital literature review: measurement, reporting andmanagement. Journal of Intellectual Capital, 1(2), 155-76.

Pulic, A. (1998). Measuring the performance of intellectual potential in the knowledge economy. available at: www.measuring-ip.at

Shiu, H.-J. (2006a). Application of the VAIC method to measures of corporate performance: aquantile regression approach.The Journal of American Academy of Business, $8(2), 156-60$.

Shiu, H.-J. (2006b). The application of the value added intellectual coefficient to measurecorporate performance: 
evidence from technological firms. International Journal ofManagement, 23(2), 356-65.

Sveiby, K. E. (1997). The new Organisational Wealth. BerretKoehler Publishers Inc. San Francisco CA.

Tan, H.P., Plowman, D. and Hancock, P. (2007). Intellectual capital and financial returns ofcompanies.Journal of Intellectual Capital, 8(1), 76-95.

Ting, I.W.K. and Lean, H.H. (2009). Intellectual capital performance of financial institutions inMalaysia.Journal of Intellectual Capital, 10(4), 588-99.

Wiig, K.M. (1997). Integrating Intellectual capital and Knowledge Management. Long Range Planning, 30(3), 399-405.

Williams, M. (2000). The Association between Gender and Ethnic Diversity of Board Structureonthe Intellectual Capital Performance of Publicly Listed Companies from an EmergingEconomy: Evidence from South Africa, available at: ww.vaic-on.net/download/Paper3.pdf

Williams, S. M. (2001). Is intellectual capital performance and disclosure practices related? Journal of Intellectual Capital, 2(3), $192-203$.

Zeghal, D. and Maaloul, A. (2010). Analysing value added as an indicator of intellectual capitaland its consequences on company performance.Journal of Intellectual Capital, 11(1), 39-60. 